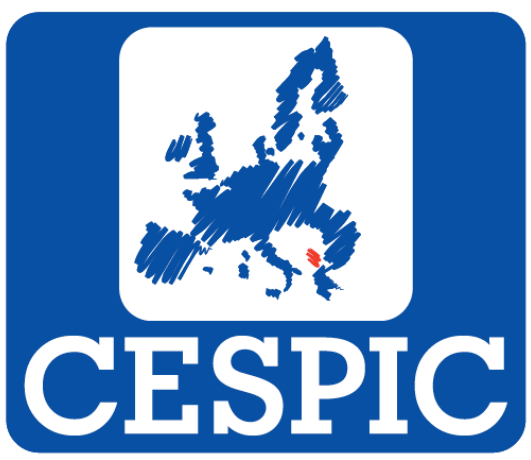

Centro Europeo di Scienza della Pace Integrazione e Cooperazione

\title{
REGULATIONS AND CORPORATE ENVIRONMENTAL RESPONSIBILITY: EVIDENCE FROM A PANEL OF FIRMS IN TRANSITION ECONOMIES
}

Antonella Biscione, Dorothée Boccanfuso, Annunziata de Felice

\section{CESPIC WORKING PAPER $2021 / 02$}




\title{
Regulations and Corporate Environmental Responsibility: evidence from a panel of firms in Transition Economies
}

\author{
Antonella Biscione \\ Department of Bioeconomic Strategies in the European Union and in the Balkans \\ CESPIC, Catholic University Our Lady of Good Counsel \\ a.biscione@unizkm.al \\ Dorothée Boccanfuso \\ Faculté de Gouvernance, Sciences Economiques et Sociales, Université Mohammed VI \\ Polytechnique \\ dorothee.boccanfuso@um6p.ma \\ Annunziata de Felice \\ Department of Law, University of Bari Aldo Moro \\ annunziata.defelice@uniba.it
}

\begin{abstract}
The aim of this study is to investigate how a set of regulations influences the pro-environmental actions of firms in a panel of 25 Transition Countries. For this purpose, we use the enterprise survey data developed by the European Bank for Reconstruction and Development (EBRD), the European Investment Bank (EIB) and the World Bank Group (WBG). Based on a logit modeling and on the construction of different indicators characterizing the environmental actions of the firms, we find that regulation affects positively the decision of firms to implement an eco-action. Results are confirmed when we examine the different eco-action categories. Findings obtained from the interactions are also worthy of note. In particular, we find that board of directors are more prone to consider shareholder interests, and a strong network effect emerges between EU candidate countries and EU economies.
\end{abstract}

Keywords: Corporate Environmental Responsibility; Manufacturing Firms; Regulation; Transition countries

Jel Codes: M14; L60; Q58 


\section{Introduction}

In the latest years, the acceleration of environmental problems has prompted firms to undertake their social and environmental responsibility. The attention paid to the issue of Corporate Environmental Responsibility (hereinafter CER) has increased among scholars and policymakers. According to Surroca et al. (2010), CER is defined as "the broad array of strategies and operating practices that a company develops in its efforts to deal with and create relationships with its numerous stakeholders and the natural environment". In other words, CER can be viewed as a distinct component with respect to the Corporate Social Responsibility (CSR)1 (Qin et al., 2019; Wang, 2016; Timpere, 2008), a form of self-regulation (Agudo-Valiente et al., 2017) since companies decide to include the environmental aspects in their business strategies.

Firms themselves are increasingly aware that CER is becoming relevant. This proactive environmental approach ${ }^{2}$ is encouraged by the European Commission both within the European Union (Punzo et al., 2019) and in other external areas that aim to join the European Union (Kudlak, 2017). However, despite the EU directives, there are significant differences between the European Member States in the implementation of CER (Punzo et al., 2019; Galvez-Martos et al., 2013).

A substantial literature has explored both drivers and barriers of corporate social and environmental responsibility in developed countries (i.e. Agudo-Valiente et al., 2017; Galvez-Martos et al., 2013; Murillo-Luna et al., 2011; Laudal, 2011) recognizing their importance for business and reputation (Bux et al., 2020). Other studies have investigated the drivers and barriers of the CER and CSR in different sectors (Gohoungodji et al., 2020; Bello and Kamanga, 2018; Goyal and Kumar, 2017; Tsai et al., 2016) and in some developing countries (Bux et al., 2020; Hossain et al., 2016) such as India and China (Goyal and Kumar, 2017; Shen et al., 2015; Graafland and Zhang, 2014). Few studies investigate the Corporate environmental strategies in other

\footnotetext{
1 According to the European Commission (2011), CSR is "the responsibility of enterprises for their impacts on society". To fully meet their social responsibility, companies "should have in place a process to integrate social, environmental, ethical, human rights and consumer concerns into their business operations and core strategy in close collaboration with their stakeholders, with the aim of maximizing the creation of shared value for their owners/shareholders and civil society at large and identifying, preventing and mitigating possible adverse impacts".

2 The literature on CER distinguishes between environmental reactivity approach and environmental proactivity approach of firms. According to the first, firms introduce the minimal change to comply with the regulations. The second approach states that firms voluntarily adopt strategies to reduce their effect on the environment (Gonzalez-Benito and Gonzalez-Benito, 2005).
} 
emerging economies and Transition countries (Earnhart et al., 2014; Sindhi and Kumar, 2012).

Given the lack of empirical evidence on the relationship between regulation and firms' environmental actions for Transition countries, this study aims to fill this gap by employing firm-level data drawn from the World Bank Enterprise Surveys. These surveys are conducted periodically and are a part of a joint project of the European Bank for Reconstruction and Development (EBRD) the European Investment Bank (EIB) and the World Bank Group (WBG). The surveys contain details on several topics such as business environmental indicators, innovation, organization and management practices, employees, relationship between enterprises and government, green aspects, and other general information about enterprises.

In this paper, we study empirically the influence that regulation has on the environmental actions of manufacturing firms in a panel of 25 Transition countries.

The main findings obtained through the estimation show that regulation strongly impact on the firm's decision to adopt environmental action. This result is also confirmed observing the different categories of eco-actions. Interactions also show some interesting results. When we interact the board of directors with regulation, we find that firms with board of directors are more focused on protecting shareholder interests. Furthermore, the interactions between non-EU and EU candidate countries with neighboring EU countries respectively, confirm the existence of network effects that are triggered by the proximity $\mathrm{w}$ to EU countries.

The remainder of this paper is organized as follows. Section 2 focuses on the literature review and conceptual background of the role of regulations on Corporate Environmental Responsibility. Section 3 describes the data and the variables, while Section 4 outlines the econometric strategy and presents the findings of baseline model. In the following section, some alternative estimations are presented. Finally, the last section concludes the article.

\section{Theoretical background}

Most of the CER research at firm level focuses mainly on the determinants that influence pro-environmental actions (Qin et al., 2019, Jiang et al., 2018; Liu, 2018, Leonidou et al., 2017; Nulkar, 2014; Murillo-Luna et al., 2011; Darnal et al., 2010; Aragón-Correa et al., 2008; Molina-Azorin et al., 2009; Murillo-Luna et al., 2008). 
Other studies investigate the association between firm's environmental and social actions with its reputation (Lloyd-Smith and An, 2019; Martin de Castro et al., 2019); the effect of CER on firm's performance (Do and Nguyen , 2020; Jo et al., 2015); the relationship between environmental strategies and firms' competitive advantage (Do and Nguyen , 2020; Sindhi and Kumar, 2012); and finally, the association among the firms' environmental activities and share price (Hussainey and Salama, 2010).

There is also a strand of literature that explores the role of regulation on the environmental proactive strategies of firms. In particular, two theories seem to emerge: the institutional and stakeholder approaches. According to the institutional literature (i.e. North, 1990; Scott, 1991; Delmas et al., 2011; Delmas and Toffel, 2008), regulation, considered as external determinants (Saleem et al., 2020; Valero-Gil et al., 2017; Sindhi and Kumar, 2012), affects the firm's environmental strategies. In addition, this literature explains the reason why firms adopt environmental decisions when rules are imposed (Do and Nguyen, 2020). The second approach namely the stakeholder theory (Freeman, 1984), emphasizes the role of regulators, included among the stakeholders and able to influence the firms' environmental decisions with its pressure (Hossain et al., 2016; Rasi et al., 2013). In other papers, regulation could be categorized as both external drivers and, in some cases the main external obstacles to the environmental strategies for its complex nature (Qin et al., 2019; Earnhart et al., 2014; Sindhi and Kumar, 2012). In fact, on one hand, regulation could be considered as an additional cost for a firm, on the other hand, it could be perceived as an opportunity to invest in environmental projects, improve firms' efficiency (Rexhauser and Rammer, 2014; Popp, 2010), and re-distribute R\&D activities for decreasing firms' environmental impact (Lanoie et al., 2011). Most studies on the effect of CER are carried out on developed countries providing ambiguous results. Some studies focusing on the barriers of proactive environmental strategy find that complex or unclear regulations are a strong limitation for firm's environmental activities (Gonzàlez-Torre et al., 2010; Murillo-Luna et al., 2011). Other recent studies (Agudo-Valiente et al., 2017; Galvez-Martos et al., 2013) show that industrialized countries have well-defined environmental regulations as a consequence of the high-level interest, also from a social point of view, in environmental issues (Qin et al., 2019). Therefore, in these countries, regulation (Murillo-Luna et al., 2008, 2011; Delgado-Ceballos, 2011) and regulatory stakeholder pressure (Valero-Gil et al., 2017; Murillo-Luna et al., 2008; Sarkis et al., 2010) are the 
most important external factor to drive the firms' environmental practices. Differently from developed economies, in some developing countries regulation as well as institutional systems are weak, and the environmental standards are low (Jamali and Karam, 2016; Sindhi and Kumar, 2012). Then, the pressure that companies receive from internal institutions is low and they are more influenced by international level (Ali et al., 2017). When the institutions are weak and influenced by corruption and industrial lobbies, many firms receive incentives to adopt environmental voluntary strategies and to participate in certification programs (Earnhart et al., 2014; Tambunlertchai et al., 2013). For this reason, in developing economies, environmental and social regulations with institutions play a crucial role in directing firms' environmental actions (Saleem et al., 2020; Chen et al., 2018; Earnhart et al., 2014; Sindhi and Kumar, 2012) even if, environmental and social regulations could be poorly enforced (Blackman, 2010). In addition, the regulation's application increases costs and constrains the managers' choices (Berchicchi et al., 2017). In other developing countries, the CER is primarily driven by the government, which plays a dominant role in enterprise environmental compliance (Qin et al., 2019) and consequently environmental legislation is strictly enforced (Bao et al., 2013).

Different forms of regulation include the legal framework that refers to compliance with industry standards (Sindhi and Kumar, 2012). Especially in developing countries findings are mixed. On the one hand, the legal framework is considered as external barrier since the costs incurred by firms to comply with the industry standards discourage mainly firms with limited financial resources to be invested in compliance equipment (Armah et al., 2011). On the other, legal framework is considered as an opportunity for firms in developing countries, when companies implement environmental strategies and increase environmental compliance (Luken et al., 2008) due to market pressure (Shindi and Kumar, 2012).

Only few papers, based on descriptive statistics focuses on the role of regulation in CER strategies of Transition economies. Harangzó et al., (2010) explore the drivers of CER in Hungarian companies. Using a database of the OECD survey (2003) based on a sample of 4,186 facilities, the authors find that among the main drivers, the international environmental policies with the consequent implementation of the EU standards, influence firms' environmental decisions. The study of Seroka-Stolka and Lukomska-Szarek (2016) analyzes the barriers to the adoption of proactive 
environmental actions in 156 Polish firms through a survey. The results show that among the external barriers, "the scares flexibility in regulation compliance times" is in last position. Also, the paper of Kudlak (2017) that investigates the drivers of firms' environmental activities in Poland deserves particular attention. Using survey data collected from 283 companies which assume as legal framework a form of environmental voluntary program represented by the EU standard during the period 1996-2006, he shows that a potential barrier to international trade for a green firm is the EU standard certification. Yet, this study finds that during the transition process, the firms' effort to join the EU standards is considered a source of pressure for companies to export in these economies (Qi et al., 2011). Therefore, the aim of this study is to contribute to the literature on environmental proactive strategies of firms by enriching this particular strand examining a panel of 25 Transition countries.

\section{Data collection and variables}

To explore the impact of regulation on firm's activities for the environment, in this paper we use firm-level data collected by the World Bank's Enterprise Surveys (hereinafter ES) and, in some specifications, we match them with other indicators taken from other databases. The ES were conducted between October 2019 and March $2020^{3}$ and were a part of a joint project of the European Bank for Reconstruction and Development (EBRD), the European Investment Bank (EIB) and the World Bank Group (WBG).

These surveys are based on uniform sampling technics that have been applied in nearly 140 countries since 2002. Particularly, the surveys were carried out according to a two-step procedure. The first step is to apply a telephone screener questionnaire to check suitability and establish appointments. Then a face-to-face interview is conducted with the Manager/Owner/Manager of each firm.

The survey's focus is to provide information on firms operating in the private sector. The universe of the study is represented by the non-agricultural economy ${ }^{4}$ that includes: all manufacturing sectors, construction, services, transport, storage, communications and IT in accordance with the group division ISIC Revision 3.1.

\footnotetext{
${ }^{3}$ For information on the period in which the surveys were carried out see table A1 in the Appendix

${ }^{4}$ Excluded sectors are financial intermediation, real estate and renting activities and finally, public and utilities.
} 
The surveys provide a sample representative of firms that have been selected following the stratified random sample methodology ${ }^{5}$. The surveys also offer detail on: (i) the innovation behavior of firms, (ii) innovative activities, organization practices, management and employees and (iii) other general information on firms. In recent surveys, a new section has been included on environment aspects, this gives us the opportunity to examine and compare the effect of regulation on eco-actions for firms across transition countries. It is based on data from about 15,246 firms from 25 countries of Eastern Europe and Central Asia. At the beginning of the 1990s, all the countries examined had carried out significant changes in order to implement the transition from centrally planned economy to liberal market economies.

The changes that have involved these countries have first of all concerned the legal, institutional, market and civil society as a whole, but they have also influenced the field of environmental protection and management (Clark and Cole, 1998, Friesenbichler et al., 2016, Kudlack, 2017, Biscione et al., 2021).

Eco-action is the dependent variable equal to 1 if the firm, in the last three years, has adopted at least one environmental measure ${ }^{6}$, and 0 otherwise. The main explanatory variable of interest is the regulation. In order to study the effect of a regulation as a whole on actions for the environment adopted by firms, we use the three variables that capture regulation: (i) occupational safety regulations, (ii) health and hygiene regulations and finally (iii) environmental regulations. According to literature (Ashford and Caldart, 2010; Aalders and Wilthagen; 1997) these three regulations are

\footnotetext{
5 The stratification levels are three and they are as follows: region, sector and firm dimension.

${ }^{6}$ The environmental measures are the following: (i) heating and cooling improvements; (ii) more climatefriendly energy generation on site; (iii) machinery and equipment upgrades; (iv) energy management; (v) waste minimization, recycling and waste management; (vi) air pollution control measures; (vii) water management; (vii) upgrades of vehicles; (viii) improvements to lighting systems and finally (ix) other pollution control measures.
} 
interconnected and are the basic regulations that a firm can apply. We believe that these regulations reflect the possibility to implement the environmental voluntary actions. In other words, companies that do not apply these basic regulations could hardly promote voluntary actions.

Therefore, to observe the overall effect of these three types of regulation we create a unique indicator performing the principal component analysis (PCA). We employ the PCA since it allows us to reduce the dimensionality of the data by choosing the most significant features that capture maximum information on the dataset.

Several control variables are included in the analysis to account for other factors that are likely to affect firms' eco-actions. To assess the impact of board of directors on the decision to implement an eco-action, we consider a dummy variable taking the value 1 whether the firm has a board of directors or a supervisory board, 0 otherwise. To evaluate if manager females are more sensitive to environmental issues, we add a dummy variable that shows if a firm has a top manager female. Firm age is measured as the difference between the year of that the survey and the year in which the firm start its business activity. Other characteristics are also considered: (i) size, an ordered variable that is equal to 1 for small firms (5-19 employees), 2 for medium firms (20-99 employees) and 3 for large firms (more than 100 employees); (ii) the geographic dimension of markets and (iii) whether the firm is an independent economic unit (taking the value of 1 ) or part of a group of firms (taking 0 ). We also employ a sector variable: firms are grouped in three sectors: (i) manufacturing; (ii) retail services and (iii) other services. We split our sample in four geographical regions (European Former-USSR Countries, Former Yugoslavian Countries and Albania, Eurasian Former-USSR Countries and Central European countries) to check regional differences. Finally, to investigate whether companies operating in EU member states have a greater awareness for the environment, we use a categorial variable equal to 1 for companies operating in a country that does not join to the EU, 2 for companies based in countries that belong to the EU and 3 for firms located in EU candidate countries.

Information on the opening of trade is captured by a sub-indicator of the new KOF globalization index ${ }^{7}$ (Gygli et al, 2019), namely trade globalization index. Finally,

\footnotetext{
${ }^{7}$ Kof Index for overall globalization is a composite index that includes 24 economic, social and political variables. The index is between 0 (as fully closed) and 100 (as fully open). Data have been available since 1970 on an annual basis for 208 countries and they are updated annually by the KOF Swiss Economic Institute.
} 
details on the state of sustainability in the countries considered are summarized by the Environmental Performance Index developed by Yale University and Columbia University in collaboration with the World Economic Forum and the Joint Research Centre of the European Commission.

Table A2 in the Appendix contains the description of variables to account for factors that could affect the propensity of a firm to have a proactive behavior for the environment. Table 1 reports the descriptive statistics.

Table 1. Descriptive statistics of variables

\begin{tabular}{|c|c|c|c|c|c|}
\hline Variable & Obs & Proportion & Mean & Std. Err. & Std.Dev \\
\hline Eco-actions & 14655 & 0.78 & & 0.003 & \\
\hline Regulation & 14303 & & $-9.28 \mathrm{E}-09$ & & 0.99 \\
\hline Manager Female & 15226 & 0.21 & & 0.003 & \\
\hline Board Director & 15192 & 0.27 & & 0.004 & \\
\hline Firm Dimension & 15243 & & & & \\
\hline Small Firms & & 0.46 & & 0.004 & \\
\hline Medium Firms & & 0.32 & & 0.004 & \\
\hline Large Firms & & 0.22 & & 0.003 & \\
\hline Sector activity & 15246 & & & & \\
\hline Manufacturing & & 0.55 & & 0.004 & \\
\hline Retail Services & & 0.2 & & 0.003 & \\
\hline Other Services & & 0.25 & & 0.003 & \\
\hline Firm's age & 15099 & & 18.16 & & 14.16 \\
\hline Affiliation & 15244 & 0.10 & & 0.002 & \\
\hline Market Sales & 15030 & & & & \\
\hline More National Sales & & & 0.68 & 0.004 & \\
\hline National and International Sales & & & 0.29 & 0.004 & \\
\hline More International Sales & & & 0.03 & 0.001 & \\
\hline Trade Globalization & 14975 & & 68.41 & & 17.46 \\
\hline Environmental Performance & 14975 & & 78.51 & & 7.40 \\
\hline Country Regions & 15246 & & & & \\
\hline European Former-USSR Countries & & 0.35 & & 0.004 & \\
\hline Central European Countries & & 0.25 & & 0.004 & \\
\hline Former Yugoslavian Countries and Albania & & 0.18 & & 0.003 & \\
\hline Eurasian Former- USSR Countries & & 0.22 & & 0.003 & \\
\hline European Union & 15246 & & & & \\
\hline Non-EU Countries & & 0.54 & & 0.004 & \\
\hline European Union Countries & & 0.38 & & 0.004 & \\
\hline Candidate EU Countries & & 0.08 & & 0.002 & \\
\hline
\end{tabular}

\section{Empirical model and results}

As mentioned above, our dependent variable has a discrete distribution, we therefore apply qualitative techniques using a probit regression model to identify the effect of regulation on eco-actions in Transition countries. Probit model is a class of latent variable threshold models for the analysis of binary data. In this model, we assume that the binary response is the indicator of the event that a latent variable not observed exceeds a given threshold to induce the enterprise to implement an eco-action. As mentioned in the previous section, "Eco-action" is the dependent binary variable. The

Differently from the original globalization index, the revised KOF globalization index allows us to observe different dimensions of globalization. 
parameters of the probit regression are estimated with the maximum likelihood approach. We use probit estimates of the marginal effects of independent variables to give an interpretation of their related effects. Thus, the binary probit regression model can be specified as:

$$
y_{i}= \begin{cases}1 & \text { if } y_{i}^{*}=x_{i}^{\prime} \beta+\varepsilon_{i}>0 \\ 0 & \text { if } y_{i}^{*}=x_{i}^{\prime} \beta+\varepsilon_{i} \leq 0\end{cases}
$$

where $y_{i}$ is the observed binary variable for eco-action, $y_{i}^{*}$ is an unobserved latent variable that defines the probability of engaging in eco-action, $x_{i}^{\prime}$ is a vector of determinants affecting firms' decision to undertake an environmental strategy and finally $\varepsilon_{i}$ represents the error term. Table 2 reports the results.

\section{Table 2- Estimation results: Regulation and Eco-actions}

\begin{tabular}{|c|c|c|c|c|}
\hline VARIABLES & $\begin{array}{c}1) \\
\text { Eco-actions } \\
\end{array}$ & $\begin{array}{c}(2) \\
\text { Eco-actions } \\
\end{array}$ & $\begin{array}{c}(3) \\
\text { Eco-actions } \\
\end{array}$ & $\begin{array}{c}(4) \\
\text { Eco-actions }\end{array}$ \\
\hline Regulation & $\begin{array}{c}0.045^{* * *} \\
(0.012)\end{array}$ & $\begin{array}{c}0.045^{* * * *} \\
(0.012)\end{array}$ & $\begin{array}{c}0.044^{* * *} \\
(0.012)\end{array}$ & $\begin{array}{c}0.044^{* * *} \\
(0.012)\end{array}$ \\
\hline \multicolumn{5}{|l|}{ Ref. Other Services } \\
\hline Manufacturing & $\begin{array}{l}0.084^{* *} \\
(0.030)\end{array}$ & $\begin{array}{l}0.077 * * * \\
(0.030)\end{array}$ & $\begin{array}{c}0.124^{* * *} \\
(0.031)\end{array}$ & $\begin{array}{l}0.119 * * * \\
(0.031)\end{array}$ \\
\hline Retail Services & $\begin{array}{l}-0.041 \\
(0.036)\end{array}$ & $\begin{array}{l}-0.034 \\
(0.036)\end{array}$ & $\begin{array}{l}-0.026 \\
(0.036)\end{array}$ & $\begin{array}{l}-0.028 \\
(0.036)\end{array}$ \\
\hline \multicolumn{5}{|l|}{ Ref: Small Firms } \\
\hline Medium Firms & $\begin{array}{c}0.122^{* * *} \\
(0.029)\end{array}$ & $\begin{array}{c}0.118^{* * *} \\
(0.029)\end{array}$ & $\begin{array}{c}0.135^{* * *} \\
(0.029)\end{array}$ & $\begin{array}{c}0.128^{* * *} \\
(0.029)\end{array}$ \\
\hline Large Firms & $\begin{array}{c}0.185^{* * *} \\
(0.037)\end{array}$ & $\begin{array}{c}0.168^{* * *} \\
(0.037)\end{array}$ & $\begin{array}{c}0.223^{* * *} \\
(0.038)\end{array}$ & $\begin{array}{c}0.212^{* * *} \\
(0.038)\end{array}$ \\
\hline Board of directors & $\begin{array}{c}0.335^{* * *} \\
(0.032)\end{array}$ & $\begin{array}{c}0.352^{* * * *} \\
(0.032)\end{array}$ & $\begin{array}{c}0.328^{* * *} \\
(0.032)\end{array}$ & $\begin{array}{c}0.330^{* * * *} \\
(0.033)\end{array}$ \\
\hline Female Manager & $\begin{array}{l}-0.095^{* * *} \\
(0.030)\end{array}$ & $\begin{array}{l}-0.087^{* * *} \\
(0.030)\end{array}$ & $\begin{array}{c}-0.072^{* *} \\
(0.030)\end{array}$ & $\begin{array}{c}-0.074^{* *} \\
(0.030)\end{array}$ \\
\hline Firm's Age & $\begin{array}{l}-0.000 \\
(0.001)\end{array}$ & $\begin{array}{c}0.000 \\
(0.001)\end{array}$ & $\begin{array}{l}-0.000 \\
(0.001)\end{array}$ & $\begin{array}{l}-0.000 \\
(0.001)\end{array}$ \\
\hline Affiliation & $\begin{array}{c}0.124^{* * *} \\
(0.045)\end{array}$ & $\begin{array}{l}0.128^{* * *} \\
(0.045)\end{array}$ & $\begin{array}{c}0.128^{* * *} \\
(0.045)\end{array}$ & $\begin{array}{c}0.119^{* * * *} \\
(0.045)\end{array}$ \\
\hline \multicolumn{5}{|l|}{ Ref. Firms sell only on national Market } \\
\hline Firms sell only on international market & $\begin{array}{c}0.079 \\
(0.073)\end{array}$ & $\begin{array}{c}0.076 \\
(0.073)\end{array}$ & $\begin{array}{l}-0.009 \\
(0.075)\end{array}$ & $\begin{array}{l}-0.012 \\
(0.075)\end{array}$ \\
\hline Firms sell on national and international market & $0.181^{* * *}$ & $0.204^{* * *}$ & $\begin{array}{c}0.166^{* * *} \\
(0.032)\end{array}$ & $\begin{array}{c}0.181^{* * * *} \\
(0.032)\end{array}$ \\
\hline Trade Globalization & & & $\begin{array}{c}0.006^{* * *} \\
(0.001)\end{array}$ & $\begin{array}{c}0.010^{* * *} \\
(0.001)\end{array}$ \\
\hline Environmental Performance & & & $\begin{array}{l}-0.023^{* * *} \\
(0.002)\end{array}$ & $\begin{array}{c}-0.0154^{* * *} \\
(0.002)\end{array}$ \\
\hline $\begin{array}{l}\text { Ref. European Union Countries } \\
\text { Non-EU Countries }\end{array}$ & $\begin{array}{c}-0.165^{* * *} \\
(0.028)\end{array}$ & & $\begin{array}{c}-0.258^{* * *} \\
(0.042)\end{array}$ & \\
\hline Candidate EU Countries & $\begin{array}{l}-0.220 * * * \\
(0.046)\end{array}$ & & $\begin{array}{c}-0.347^{* * *} \\
(0.049)\end{array}$ & \\
\hline \multicolumn{5}{|l|}{ Ref. Central European Countries } \\
\hline European Former-USSR Countries & & $\begin{array}{c}-0.129 * * * \\
(0.033)\end{array}$ & & $\begin{array}{l}-0.043 \\
(0.067)\end{array}$ \\
\hline Former Yugoslavian Countries and Albania & & $\begin{array}{c}-0.110^{* * *} \\
(0.039)\end{array}$ & & $\begin{array}{c}-0.171^{* * *} \\
(0.042)\end{array}$ \\
\hline Eurasian Former- USSR Countries & & $\begin{array}{l}-0.126^{* * *} \\
(0.037)\end{array}$ & & $\begin{array}{c}0.041 \\
(0.067)\end{array}$ \\
\hline Constant & $\begin{array}{c}0.676^{* * *} \\
(0.037)\end{array}$ & $\begin{array}{c}0.647^{* * *} \\
(0.400)\end{array}$ & $\begin{array}{c}2.115^{* * *} \\
(0.188)\end{array}$ & $\begin{array}{c}1.088^{* * *} \\
(0.218)\end{array}$ \\
\hline Observations & 13,539 & 13,539 & 13,332 & 13,332 \\
\hline
\end{tabular}

Table 2 collects the empirical results. Specifically, findings in columns 1 and 3 refer to a baseline model with the information concerning whether firms are localized in EU 
member states, in EU candidate states or in countries that do not join to the EU. Column 2 and 4 present results of the model that includes globalization and the environmental performance index and the classification of the states considered in four macro-areas. In contrast with the theoretical expectations (Jamali and Karam, 2016; Ali et al. 2017, Sindhi and Kumar, 2012), the main findings confirm the role of regulation captured by the composite regulation index, on the firm's propensity to adopt pro-active environmental strategies. This means that in Transition economies firms when adopt the regulation are more sensitive to the introduction of eco-action strategies.

Other results highlight that firms operating in manufacturing sector are willing to implement environmental actions with respect to other service sectors since manufacturing sector is highly polluting (Harangzó et al., 2010). However, a piece of literature highlights that the service sector is more sensitive to pursue environmental strategies (Do et al., 2020). Probably, findings depend on the specificity of the countries analyzed. Yet, firms with board directors have a positive effect on the propensity to implement pro-environmental strategies. Firms managed by men are more supportive of eco-actions than female-led firms. The result is in contrast with the literature that finds how female-led boards are more responsive to social and environmental actions (Lu and Herremans, 2019; Bear et al., 2010). Looking at the firm size, we find that large and medium firms are more likely to adopt environmental strategies than small ones. In particular, larger firms are associated with environmental proactiveness to a greater extent than smaller firms (Etzion, 2007) since they have greater visibility, also from a societal point of view (Etzion, 2007; Jiang and Bansal, 2003). It follows that stakeholders and regulators could intensify their requests for large companies to adopt more proactive environmental practices (Do et al., 2020; Earnhart et al., 2014; Darnall et al., 2010). In addition, larger firms have more resources to spend on environmental actions (Leonidou et al., 2017), on the contrary, smaller firms are less likely to invest in environmental practices that have long run strategic benefits (Darnall et al., 2010; Bianchi and Noci, 1998).

Furthermore, corporate affiliation is strongly significant and positively associated to environmental strategies. It depends probably on the headquarter which transposes the regulation and applies it in the branches. Considering the geographical market, firms that sell both in domestic and international market are more aware of environmental issues and are more likely to implement eco-actions with respect to the firms that sell 
more domestically. In other words, in Transition countries, the local firms opened to foreign trade are re-organized themselves and have adopted EU environmental standards to be more competitive on the international market (Kudlak, 2017).

With regard to the effect of globalization on the propensity of firms to be proactive in their environmental behavior, findings show that globalization has a positive effect on firms' eco-actions. This suggests that globalization is one of the market forces that contributes to improvements in corporate governance since firms comply with standards despite the absence of government sanctions (Shindi and Kumar, 2012; Bansal and Roth, 2000). Also, the Environmental Performance Index that capture the level of sustainability in Transition economies taken into account is significant but negatively associated with the proactive environmental actions.

The plausible explanation is that, with reference to some environmental problems, there could be a process of replacement, in the sense that the more the institutions tackle this issue, the less firms have to take care of it. In other words, firms benefit from the measures introduced by the institutions without incurring any additional costs.

Moreover, findings show that companies operating in EU member states have a higher awareness for the environment. In fact, taking EU Countries as a reference, we can remark that firms in EU candidate countries and non-EU countries exhibit a strong but negative association with the eco-actions. We also obtain the same results when we consider the macro areas. We have chosen as a reference the Central European countries since that all economies in this area are already applying environmental regulations in compliance with European standards. As a result, these firms are more willing to implement the eco-actions. For the other three regions (European FormerUSSR Countries, Former Yugoslavian Countries and Albania, Eurasian Former-USSR) findings show a probability of employ the firms' pro-environmental activities that decrease significantly if compared to Central European countries. In fact, in these areas the application of environmental strategies is not influenced by EU standards. In addition, the environmental awareness is low, and the regulation is often uncertain (Sindhi and Kumar, 2012).

\section{Alternative estimations}

5.1 Interactions and other specifics 
In order to observe whether compliance with regulation is related to some of the firm characteristics, we run again the baseline model by considering how regulation interact with firm's characteristics. In particular, we take into account the following characteristics: (i) age; (ii)the presence of a female manager and (iii) a board of directors. These further estimations allow to examine the effect of these interactions on firms' propensity to introduce an eco-action. Then, to obtain information on the network effect (network externality), we interact the non-EU countries and EU candidate countries with the share of neighboring countries belonging to the EU to the total number of neighboring countries. These interactions could provide information on the network effect, in particular on the pressure that the neighboring countries belonging to the EU could exert on the two groups of countries considered. Table 3 reports the findings. For the sake of readability, coefficients of other variables used are not shown.

Table 3. Interactions

\begin{tabular}{|c|c|c|c|c|}
\hline VARIABLES & $\begin{array}{c}(1) \\
\text { Eco-actions }\end{array}$ & $\begin{array}{c}(2) \\
\text { Eco-actions }\end{array}$ & $\begin{array}{c}(3) \\
\text { Eco-actions }\end{array}$ & $\begin{array}{c}(4) \\
\text { Eco-actions }\end{array}$ \\
\hline Regulation & $\begin{array}{c}0.059^{* * * *} \\
(0.014)\end{array}$ & $\begin{array}{c}0.039^{* * * *} \\
(0.014)\end{array}$ & $\begin{array}{c}0.074^{* * * *} \\
(0.020)\end{array}$ & $\begin{array}{c}0.046^{* * *} \\
(0.012)\end{array}$ \\
\hline Board of Directors & $\begin{array}{c}0.331^{* * * *} \\
(0.033)\end{array}$ & & & \\
\hline Female Manager & & $\begin{array}{c}-0.066^{* *} \\
(0.030)\end{array}$ & & \\
\hline Firm's Age & & & $\begin{array}{l}-0.000 \\
(0.001)\end{array}$ & \\
\hline Non-Eu Countries & & & & $\begin{array}{c}-0.490 * * * * \\
(0.091)\end{array}$ \\
\hline Candidate Eu Countries & & & & $\begin{array}{c}-2.229^{* * *} \\
(0.675)\end{array}$ \\
\hline Environmental Performance & & & & \\
\hline Board of Directors* Regulation & $\begin{array}{c}-0.069 * * \\
(0.030)\end{array}$ & & & \\
\hline Female Manager*Regulation & & $\begin{array}{c}0.023 \\
(0.030)\end{array}$ & & \\
\hline Firm Age*Regulation & & & $\begin{array}{l}-0.002^{*} \\
(0.001)\end{array}$ & \\
\hline Non- Eu Countries* Neighboring Countries & & & & $\begin{array}{c}0.538 * * * * \\
(0.115)\end{array}$ \\
\hline Candidate Eu Countries*Neighboring Countries & & & & $\begin{array}{c}5.091 * * * * \\
(1.775)\end{array}$ \\
\hline Constant & $\begin{array}{c}2.108 * * * * \\
(0.188)\end{array}$ & $\begin{array}{c}2.115^{* * * *} \\
(0.188)\end{array}$ & $\begin{array}{c}2.115^{* * * *} \\
(0.188)\end{array}$ & $\begin{array}{c}12.834^{* * * *} \\
(1.626)\end{array}$ \\
\hline Observations & 13,332 & 13,332 & 13,332 & 13,332 \\
\hline
\end{tabular}

Findings related to firm characteristics are significant for the following interactions: (i) board of directors and regulation; (ii) firm age and regulation. The first interaction shows a significant but negative relationship with eco-actions. This means that the presence of board of directors reduces the possibility to implement pro-environmental actions. This unexpected result is in contrast with the literature (Shaukat et al., 2016) that shows firms which have as their part a board oriented to environmental issues and 
are more likely to implement actions that improve their performance in socioenvironmental context. Conversely, in our countries board of directors probably prefer to protect the interests of shareholders. Also, the second interaction reveals a significant and negative association between firm age and regulation. The plausible interpretation is that the eco-actions are implemented by the younger firms because it may be easier to implement adaptation measures in recent companies. Yet, the interaction between non-EU countries and EU candidate countries with neighboring countries is strongly significant and positively associated with the firms' pro-environmental strategies. As expected, these findings confirm the existence of network effects that arise from contiguity with EU countries. In particular, the magnitude of pressure exerted by EU countries is very high, especially towards EU candidate countries since these countries have already achieved the EU standards required by the accession process.

\subsection{Alternative types of eco-actions}

Hereafter we describe the results of alternative estimations. We have re-run the analysis so highlighting the effect of regulation on four groups of eco-actions ${ }^{8}$ namely machinery upgrades, energy save, pollution control and finally recycling waste and water management. In Table 4, we show the estimation findings.

Results are consistent with those obtained by the baseline estimate. The positive effect of regulation on the firm's decision to implement eco-actions is also confirmed when observing the different eco-action categories separately. In particular, regulation strongly impacts on air pollution control and machinery and equipment upgrade. Firm size, group affiliation, geographic dimension of market, and variable that capture the EU member state awareness show a positive and significant association with the four

\footnotetext{
8 We created four categories of eco-actions by grouping them as follows:

- Machinery upgrades: (i) machinery and equipment upgrade and (ii) upgrade of vehicles.

- Energy saving: (i) more climate-friendly energy generation on site; (ii) energy management; (iii)improvements to lighting systems and (iv) heating and cooling improvements.

- Pollution control: (i) air pollution control measures and (ii) other pollution control measures.

- Recycling waste and water management: (i) waste minimization, recycling and waste management and (ii) water management.
} 
groups of eco-actions. Differently from the baseline results, we find that companies in the manufacturing sector are more prone to adopt eco-actions whereas retail services become significantly and positively associated with energy saving and show a negative impact on air pollution control measures and machinery upgrades. In addition, the firm age as a proxy for firm's experience accumulated over time (Santamaria et al., 2009; Balasubramanian and Lee, 2008), is relevant for the energy saving actions and pollution control. Finally, trade globalization index, a driver for the eco-actions for the considered Transition countries, becomes a barrier for the pollution control. One plausible explanation is that the measures to be adopted for pollution control are more expensive and more difficult to implement through pro-environmental actions.

In sum, with respect to the main estimation highlighted in the previous section, the main results do not change. The impact of regulation on eco-actions is always positive and significant thus confirming the baseline results. 
Table 4. Effect of regulation on eco-action categories

\begin{tabular}{|c|c|c|c|c|c|c|c|c|}
\hline VARIABLES & $\begin{array}{c}\text { (1) } \\
\text { Machinery } \\
\text { Upgrades }\end{array}$ & $\begin{array}{c}(2) \\
\text { Machinery } \\
\text { Upgrades }\end{array}$ & $\begin{array}{c}(3) \\
\text { Energy } \\
\text { Saving }\end{array}$ & $\begin{array}{l}(4) \\
\text { Energy } \\
\text { Saving }\end{array}$ & $\begin{array}{c}\text { (5) } \\
\text { Pollution } \\
\text { Control } \\
\end{array}$ & $\begin{array}{c}(6) \\
\text { Pollution } \\
\text { Control }\end{array}$ & $\begin{array}{c}(7) \\
\begin{array}{c}\text { Recycling waste and water } \\
\text { management }\end{array}\end{array}$ & $\begin{array}{c}(8) \\
\text { Recycling waste and water } \\
\text { management }\end{array}$ \\
\hline Regulation & $\begin{array}{l}0.052^{* * * *} \\
(0.011)\end{array}$ & $\begin{array}{l}0.052^{* * *} \\
(0.011)\end{array}$ & $\begin{array}{c}0.043^{* * *} \\
(0.011)\end{array}$ & $\begin{array}{c}0.042^{* * *} \\
(0.012)\end{array}$ & $\begin{array}{c}0.060^{* * *} \\
(0.012)\end{array}$ & $\begin{array}{l}0.059^{* * *} \\
(0.012)\end{array}$ & $\begin{array}{c}0.032^{* * *} \\
(0.011)\end{array}$ & $\begin{array}{c}0.032^{* * *} \\
(0.011)\end{array}$ \\
\hline \multicolumn{9}{|l|}{$\begin{array}{l}\text { Ref. Other Services } \\
\text { Manufacturing }\end{array}$} \\
\hline Retail Services & $\begin{array}{l}(0.028) \\
-0.086^{* *} \\
(0.034)\end{array}$ & $\begin{array}{l}(0.028) \\
-0.073^{* *} \\
(0.034)\end{array}$ & $\begin{array}{l}(0.028) \\
0.116^{* * *} \\
(0.034)\end{array}$ & $\begin{array}{l}(0.029) \\
0.142^{* * *} \\
(0.035)\end{array}$ & $\begin{array}{c}(0.031) \\
-0.115^{* * *} \\
(0.039)\end{array}$ & $\begin{array}{l}(0.032) \\
-0.063 \\
(0.040)\end{array}$ & $\begin{array}{c}(0.028) \\
0.011 \\
(0.033)\end{array}$ & $\begin{array}{c}(0.028) \\
0.024 \\
(0.034)\end{array}$ \\
\hline \multicolumn{9}{|l|}{ Ref: Small Firms } \\
\hline Medium Firms & $\begin{array}{c}0.099^{* * * *} \\
(0.026)\end{array}$ & $\begin{array}{c}0.105^{* * *} \\
(0.026)\end{array}$ & $\begin{array}{c}0.124^{* * *} \\
(0.027)\end{array}$ & $\begin{array}{c}0.138 * * * \\
(0.027)\end{array}$ & $\begin{array}{c}0.124^{* * * *} \\
(0.029)\end{array}$ & $\begin{array}{c}0.142^{* * *} \\
(0.030)\end{array}$ & $\begin{array}{c}0.143^{* * *} \\
(0.028)\end{array}$ & $\begin{array}{c}0.145^{* * * *} \\
(0.026)\end{array}$ \\
\hline Large Firms & $\begin{array}{l}0.195^{* * * *} \\
(0.032)\end{array}$ & $\begin{array}{l}0.234^{* * * *} \\
(0.033)\end{array}$ & $\begin{array}{l}0.181^{* * * *} \\
(0.034)\end{array}$ & $\begin{array}{l}0.215^{* * * *} \\
(0.035)\end{array}$ & $\begin{array}{l}0.277^{* * * *} \\
(0.035)\end{array}$ & $\begin{array}{l}0.300^{* * * *} \\
(0.035)\end{array}$ & $\begin{array}{l}0.275^{* * * *} \\
(0.032)\end{array}$ & $\begin{array}{l}0.290^{* * * *} \\
(0.033)\end{array}$ \\
\hline Board of directors & $0.233^{* * *}$ & $0.224^{* * *}$ & $0.260^{* * *}$ & $0.254^{* * * *}$ & $0.277^{* * *}$ & $0.241^{* * *}$ & $0.210^{* * *}$ & $0.206^{* * *}$ \\
\hline \multirow[t]{2}{*}{ Female Manager } & $-0.115^{* * * *}$ & $-0.099^{* * *}$ & -0.046 & -0.020 & $-0.158^{* * *}$ & $-0.115^{* * * *}$ & -0.016 & $\begin{array}{l}(0.027) \\
-0.003\end{array}$ \\
\hline & $(0.028)$ & $(0.028)$ & $(0.028)$ & $(0.029)$ & $(0.032)$ & $(0.032)$ & $(0.028)$ & $(0.028)$ \\
\hline Firm's Age & $\begin{array}{c}-0.001 \\
0.001\end{array}$ & $\begin{array}{l}-0.001 \\
-0001\end{array}$ & 0.001 & $0.002^{*}$ & 0.000 & $0.001^{*}$ & 0.001 & 0.001 \\
\hline Affiliation & $\begin{array}{l}0.135^{* * *} \\
(0.038)\end{array}$ & $\begin{array}{l}0.141^{* * *} \\
(0.038)\end{array}$ & $\begin{array}{l}0.124^{* * * *} \\
(0.040)\end{array}$ & $\begin{array}{l}0.134^{* * * *} \\
(0.040)\end{array}$ & $\begin{array}{c}(.001) \\
0.004 \\
(0.040)\end{array}$ & $\begin{array}{c}(0.028 \\
0.040)\end{array}$ & $\begin{array}{c}(0.001) \\
0.111^{* * *} \\
(0.037)\end{array}$ & $\begin{array}{c}(0.001) \\
0.112^{* * *} \\
(0.038)\end{array}$ \\
\hline \multicolumn{9}{|l|}{ Ref. Firms sell only on national Market } \\
\hline Firms sell only on international market & $\begin{array}{c}0.211^{* * *} \\
(0.065)\end{array}$ & $\begin{array}{l}0.152^{* * *} \\
(0.066)\end{array}$ & $\begin{array}{c}0.072 \\
(0.068)\end{array}$ & $\begin{array}{c}0.022 \\
(0.068)\end{array}$ & $\begin{array}{l}0.102 \\
(0.068)\end{array}$ & $0.123^{*}$ & $\begin{array}{l}0.064 \\
(0.064)\end{array}$ & $\begin{array}{l}0.055 \\
(0.065)\end{array}$ \\
\hline \multirow[t]{2}{*}{ Firms sell on national and international market } & $0.217^{* * *}$ & $0.200^{* * * *}$ & $0.122^{* * *}$ & $0.120^{* * * *}$ & $0.150^{* * * *}$ & $0.188^{* * * *}$ & $0.152^{* * *}$ & $0.149^{* * * *}$ \\
\hline & $(0.027)$ & $(0.028)$ & $(0.028)$ & $(0.029)$ & $(0.029)$ & $(0.030)$ & $(0.027)$ & $(0.028)$ \\
\hline Trade Globalization & & $\begin{array}{c}0.005^{* * * *} \\
(0.001)\end{array}$ & & $\begin{array}{l}0.002^{*} \\
(0.001)\end{array}$ & & $\begin{array}{l}-0.005^{* * *} \\
(0.001)\end{array}$ & & $\begin{array}{l}0.002^{*} \\
(0.002)\end{array}$ \\
\hline Environmental Performance & & $\begin{array}{l}-0.012^{* * *} \\
(0.002)\end{array}$ & & $\begin{array}{c}-0.025^{* * *} \\
(0.002)\end{array}$ & & $\begin{array}{c}-0.028^{* * * *} \\
(0.002)\end{array}$ & & $\begin{array}{c}-0.010^{* * * *} \\
(0.002)\end{array}$ \\
\hline \multirow{2}{*}{$\begin{array}{l}\text { Ref. European Countries } \\
\text { No EU Countries }\end{array}$} & & & & & & & & \\
\hline & $\begin{array}{l}-0.130^{* * * *} \\
-(0.025)\end{array}$ & $\begin{array}{l}-0.142^{* * *} \\
(0.038)\end{array}$ & $\begin{array}{l}-0.012 \\
-0.026\end{array}$ & $-0.206^{* * * *}$ & $0.235^{* * *}$ & $-0.191^{* * *}$ & $\begin{array}{l}-0.174^{* * *} \\
-(0.025)\end{array}$ & $\begin{array}{l}-0.236^{* * *} \\
(0,038)\end{array}$ \\
\hline \multirow[t]{2}{*}{ Candidate EU Countries } & $-0.100^{* *}$ & 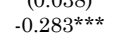 & $-0.073^{*}$ & $\begin{aligned}-0.235^{* * * *} \\
(0.07)\end{aligned}$ & $0.146^{* * *}$ & $-0.093^{*}$ & $-0.304^{* * *}$ & 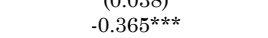 \\
\hline & $(0.041)$ & $(0.045)$ & $(0.043)$ & $(0.046)$ & $(0.046)$ & $(0.050)$ & $(0.041)$ & $(0.045)$ \\
\hline \multirow[t]{2}{*}{ Constant } & $-0.220^{* * * *}$ & $0.404^{* *}$ & $0.153^{* * *}$ & $1.993^{* * *}$ & $-1.106^{* * * *}$ & $1.629^{* * *}$ & $-0.244^{* * *}$ & 0.431 \\
\hline & $(0.042)$ & $(0.152)$ & $(0.034)$ & $(0.180)$ & $(0.037)$ & $(0.192)$ & $(0.033)$ & $(0.176)$ \\
\hline Observations & 13,277 & 13,086 & 13,244 & 13,039 & 13,124 & 12,936 & 13,288 & 13,092 \\
\hline
\end{tabular}




\section{Final remarks}

The purpose of this study was to investigate the relationship between regulation and firms' environmental actions examining a panel of 25 Transition countries by using firm-level data drawn from the World Bank Enterprise Surveys.

Empirical results show that regulation, regardless of the specification considered, has a strong and positive impact on eco-actions. Results also highlight that firms with certain characteristics seem to be more involved in environmental compliance. Clearly, our empirical evidence should be interpreted taking into account some limitations. These concern mainly the generalizability of the results since our analysis is based on a survey carried out over a short period. In fact, we use cross-sectional data, so nothing can be stated on causality. Future research exploiting panel data could empirically examine the direction of causality. Nevertheless, some suggestions for policy makers can be drawn from our results. In this context, the proximity to EU countries and the external pressure seems to have triggered eco-strategies much more than firm characteristics. This is a significant result since it points out that the neighbor spillover effect is crucial in the Transition economies as well as complying with EU standards. Then, public decision makers play a key role in targeting those firms that are already achieving environmental standards and they should implement incentive mechanisms for the other ones. In order to provide more detailed suggestions for policy makers on planning actions, further research should be conducted at the sectoral level. This type of analysis would allow the study of the peculiarities of each sector and define more specific measures.

\section{REFERENCES}

Aalders, M. and Wilthagen, T. (1997). Moving beyond command and control: reflexivity in the regulation of occupational safety and health and environment. Law and Policy, 19 (4): 415-443.

Agudo-Valiente, J.M., Garcés-Ayerbe C. and Salvador-Figueras M. (2017). Corporate social responsibility drivers and barriers according to managers' perception, evidence from Spanish firms. Sustainability, 9(10):1-24.

Ali, W., Frynas, J.G. and Mahmood, Z. (2017). Determinants of corporate social reporting (CSR) disclosure in developed and developing countries: a literature 
review. Corporate Social Responsibility and Environmental Management, 24(2):273-294.

Al-Tuwaijri S.A., Christensen T.E. and Hughes Ii, K.E. (2004). The relations among environmental disclosure, environmental performance, and economic performance: a simultaneous equations approach. Accounting, Organizations and Society, 29(5-6): 447-471.

Aragón-Correa, J.A., Hurtado-Torres, N., Sharma, S. and García-Morales, V.J. (2008). Environmental strategy and performance in small firms: A resourcebased perspective. Journal of Environnemental Management, 86(1): 88-103.

Armah, F.A., Obiri, S., Yawson, D.O., Afrifa, E.K.A. et al. (2011). Assessment of legal framework for corporate environmental behavior and perceptions of residents in mining communities in Ghana. Journal of Environmental Planning and Management, 54 (2): 193-209.

Ashford N.A. and Caldart C. (2010). Government Regulation of Environmental and Occupational Health in the Environment in the United States and the European Union. OAI, 1-31.

Balasubramanian, N. and Lee, J. (2008). Firm age and innovation. Industrial and Corporate Change, 17 (5): 1019- 1047.

Bao, Q. Shao, M. and Yang, D.L. (2013). Environmental regulation, provincial legislation and pollution emission in China, Econ. R. (in Chinese),59, 42-54.

Bear, S.E., Rahman, N. and Post C. (2010). The Impact of Board Diversity and Gender Composition on Corporate Social Responsibility and Firm Reputation. Journal of Business Ethics, 97 (2): 207-221.

Bello, F.G. and Kamanga, G. (2020). Drivers and barriers of corporate social responsibility in the tourism industry: The case of Malawi. Development Southern Africa, 37 (2): 181-196.

Berchicchi, L., Dowell, G. and King A.A. (2017). Environmental Performance and the Market for Corporate Assets. Strategic Management Journal, 38 (12): 24442464.

Biscione, A., Caruso, R. and de Felice, A. (2021). Environmental innovation in European transition countries. Applied Economics, 53 (5): 521-535.

Blackman, A. (2010). Alternative pollution control policies in developing countries. Review of Environmental Economics and Policy, 4 (2): 234-253. 
Bux, H., Zhang, Z. and Ahmad, N. (2020). Promoting sustainability through corporate social responsibility implementation in the manufacturing industry: An empirical analysis of barriers using the ISM-MICMAC approach. Corporate Social Responsibility and Environmental Management, 27:1729-1748.

Chen, C.S., Yu, C.C. and Hu, J.S. (2018). Constructing performance measurement indicators to suggested corporate environmental responsibility framework. Technological Forecasting and Social Change, 135: 33-43.

Clark, J. and Cole, D.H. (edit by), (1998). Environmental Protection in Transition. Routledge ed., London and NY.

Darnall, N., Henriques, I. and Sadorsky, P. (2010). Adopting proactive environmental strategy: The influence of stakeholders and firm size. Journal of Management Studies, 47(6): 913-1218.

Delgado-Ceballos, J., Aragon-Correa, J.A., Ortiz-de-Mandojana, N. and RuedaManzanares, A. (2011). The Effect of Internal Barriers on the Connection Between Stakeholder Integration and Proactive Environmental Strategies. Journal of Business Ethics, 107: 281-293.

Delmas, M.A. and Toffel, M.W. (2008). Organizational responses to environmental demands: Opening the black box. Strategic Management Journal, 29(10):10271055.

Delmas, M.A. and Montes-Sancho, M.J. (2011). An institutional perspective on the diffusion of the international management system standards: The case of the environmental management standards ISO 14001. Business Ethics Quarterly, 21(1): 103-132.

Do, B. and Nguyen N. (2020). The Links between Proactive Environmental Strategy, Competitive Advantages and Firm Performance: An Empirical Study in Vietnam, Sustainability, 12, 4962.

Earnhart, D.H., Khanna M. and Lyon, T.P. (2014). Corporate environmental strategies in emerging economies. Review of Environmental Economics and Policy, 8(2): 164-185.

Etzion, D. (2007). Research on Organizations and the Natural Environment, 1992Present: A Review. Journal of Managements, 33: 637-664. 
European Commission (2010). Green Paper. Audit Policy: Lessons from the Crisis. Brussels, 13.10.2010.

Freeman R.E. (1984). Strategic Management: A Stakeholder Approach, Prentice-Hall, Englewood Cliffs, NJ.

Friesenbichler, K.S. (2016). Policy interaction and the integration of volatile renewable energy. Environmental Economic Policy Studies, 18: 193-211.

Galvez-Martos, J.L., Styles, D. and Schoenberger, H. (2013). Identified best environmental management practices to improve the energy performance of the retail trade sector in Europe. Energy Policy, 63: 982-994.

Gygli, S., Haelg F., Potrafke, N. and Sturm, J-E. (2019). The KOF Globalization Index. Revisited, Review of International Organizations, 14 (3): 543-574.

Gohoungodji, P., Bernadine, N.D.A., Latulippe, J.M. and Barreto Matos, A.L. (2020) What is stopping the automotive industry from going green? A systematic review of barriers to green innovation in the automotive industry. Journal of Cleaner Production, 277:123524.

Gonzalez-Benito, J. and Gonzalez-Benito, O. (2005). Environmental proactivity and business performance: an empirical analysis. Omega, 33 (1): 1-15.

Gonzàlez-Torre, P., Alvarez, M., Sarkis, J. and Adenso-Diaz, B. (2010). Barriers to the Implementation of Environmentally Oriented Reverse Logistics: Evidence from the Automotive Industry Sector. British Journal of Management, 21:889904

Goyal P. and Kumar, D. (2017). Modeling the CSR barriers in manufacturing industries, Benchmarking: An International Journal, 24(7): 1871-1890.

Graafland, J. and Zhang, L. (2014). Corporate social responsibility in China: implementation and challenges. Business Ethics, 23(1):34-39.

Harangzó, G., Kerekes, S. and Zsóka, Á. (2010). Environmental management practices in the manufacturing sector- Hungarian features in international comparison. Journal for East European Management Studies, 15 (4): 312-347.

Hoejmose, S.U., Roehrich, J.K. and Grosvold, J. (2014). Is doing more doing better? The relationship between responsible supply chain management and corporate reputation. Industrial Marketing Management, 43 (1): 77-90. 
Høgevold, N.M. (2011). A corporate effort towards a sustainable business model: A case study from the Norwegian furniture industry. European Business Review, 23 (4): 392-400.

Hossain Md. M., Manzurul, A., Hecimovic, A., Hossain M.A. and Lema, A.C. (2016), Contributing barriers to corporate social and environmental responsibility practices in a developing country. Sustainability Accounting, Management and Policy Journal, 7 (2): 319-346.

Hussainey, K. and Salama, A. (2010). The importance of corporate environmental reputation to investors. Journal of Applied Accounting Research, 11(3): 229-241.

Jamali, D. and Karam, C. (2016). Corporate social responsibility in developing countries as an emerging field of study. International Journal of Management Review, 20(1):21-61.

Jiang, R.J. and Bansal, P. (2003). Seeing the need for ISO 14001. Journal of Management Studies, 40 (4): 1047-1067.

Jiang, Y., Xue, X. and Xue, W. (2018). Proactive corporate environmental responsibility and financial performance: Evidence from Chinese energy enterprises. Sustainability, 10(4):964.

Jo H., Kim H. and Park K. (2015). Corporate Environmental Responsibility and firm performance in the financial Service Sector. Journal of Business Ethics, 131: 257284.

Kudlak, R. (2017). Drivers of corporate environmentalism: the case of Polish economy in transition. Journal of Cleaner Production, 142 (4): 3194-3203.

Laudal, T. (2011). Drivers and barriers of CSR and the size and internationalization of firms. Social Responsibility Journal, 7: 234-256.

Lanoie, P., Laurent-Lucchetti, J., Johnstone, N. and Ambec, S. (2011). Environmental Policy, Innovation and Performance: New Insights on the Porter Hypothesis. Journal of Economics \& Management Strategy, 20 (3): 803-842.

Leonidou, L.C., Christodoulides, P., Kyrgidou, L.P., and Palihawadana, D. (2017). Internal drivers and performance consequences of small firm green business strategy: The moderating role of external forces. Journal of Business Ethics, 140:585-606.

Liu, C. (2018). Are women greener? Corporate gender diversity and environmental violations. Journal of Corporate Finance. 52:118-142. 
Lloyd-Smith, P. and An, H. (2018). Are corporate social responsibility and advertising complements or substitutes in producing firm reputation? Applied Economics, 51(6): 1-14.

Lu, J. and Herremans, I.M. (2019). Board gender diversity and environmental performance: An industries perspective. Business Strategy and the Environment, 28 (7): 1449-1464.

Luken, R., Van Rompaey, F. and Zigova, K. (2008). The determinant of EST adoption by manufacturing plants in developing countries, Ecological Economics, 66 (1): 141-152.

Martin de Castro, G., Amores-Salvadò, J., Navas -Lòpez, J.E. and BalarezoNunez, R.M. (2019). Corporate environmental reputation: Exploring its definitional landscape. Journal of Business Ethics, 29 (1): 130-142.

Molina-Azorín, J.F., Claver-Cortés, E., López-Gamero, M.D. and Tarí, J.J. (2009). Green management and financial performance: A literature review. Management Decision, 47(7):1080-1100.

Murillo-Luna, J., Garces-Ayerbe, C. and Rivera-Torres, P. (2008). Why do patterns of environmental response differ? A stakeholders' pressure approach. Strategic Management Journal, 29: 1225-1240.

Murillo-Luna, J., Garces-Ayerbe, C. and Rivera-Torres, P. (2011). Barriers to the adoption of proactive environmental strategies, Journal of Cleaner Production, 19: $1417-1425$.

North, D.C. (1990). Institutions, Institutional Change and Economic Performance, Cambridge University Press.

Nulkar, G. (2014). SMEs and environmental performance-A framework for green business strategies. Procedia Social and Behavioral Sciences, 133: 130-140.

Wagner, M. and Schaltegger, S. (2004). The effect of corporate environmental strategy choice and environmental performance on competitiveness and economic performance: an empirical study of EU manufacturing. European Management Journal, 22 (5): 557-572.

Wang, H. (2016). Systematic analysis of corporate environmental responsibility: elements, structure, function, and principles. Chinese Journal of Population Resources and Environment, 14 (2): 96-104. 
Popp, D. (2010). Innovation and Climate Policy. Annual Review of Resource Economics, 2: $275-298$.

Priyadarshini, K. and Gupta, O.K. (2003). Compliance to environmental regulations: the Indian context, International Journal of Business and Economics, 2 (1): 9-26.

Punzo, G., Panarello, D., Pagliuca, M.M., Castellano, R. and Aprile, M.C. (2019). Assessing the role of perceived value and felt responsibility on pro-environmental behaviours: a comparison across EU countries, Environmental Science and Policy, 101: 311-322.

Qi, G.Y., Zeng, S.X., Tam, C.M., Yin, H.T. et al., (2011). Diffusion of ISO 14001 environmental management systems in China: Rethinking on stakeholders' roles. Journal of Cleaner Production, 19 (11): 1250-1256.

Qin Y., Harrison, J. and Chen, L. (2019). A framework for the practice of corporate environmental responsibility in China, Journal of Cleaner Production, 235: 426452.

Rasi, R.Z.R.M., Abdekhodaee, A. and Nagarajah, R. (2013). Stakeholders' involvement in the implementation of proactive environmental practices. Management and Environmental Quality, 25 (2): 132-149.

Rexhauser, S. and Rammer, C. (2014). Environmental Innovations and Firm Profitability: Unmasking the Porter Hypothesis. Environmental \& Resouce Economics, 57 (1):145-167.

Saleem, F., Gopinath, C., Khattak, A. et al., (2020). Corporate Environmentalism: An Emerging Economy Perspective, Sustainability, 12, 6225: 1-17.

Santamaria, L., Nieto, M. J. and Barge-Gil, A. (2009). Beyond formal R\&D: Taking advantage of other sources of innovation in low-and-medium-technology industries. Research Policy, 38 (3): 507-518.

Scott, J.W. (1991). The Evidence of Experience. Critical Inquiry, 17 (4): 773-797.

Seroka-Stolka, O. and Lukomska-Szarek, J. (2016). Barriers to the adoption of proactive environmental strategies in Polish companies. 22nd International Academic Conference, Lisbon, 22 March, DOI: 10.20472/IAC.2016.022.050.

Shaukat, A., Qiu, Y. and Trojanowski, G. (2016). Board Attributes, Corporate Social Responsibility Strategy, and Corporate Environmental and Social Performance. Journal of Business Ethics, 135 (3): 569-585. 
Shen, L., Govindan, K. and Shankar, M. (2015). Evaluation of Barriers of Corporate Social Responsibility Using an Analytical Hierarchy Process under a Fuzzy Environment - A Textile Case. Sustainability, 7: 3493-3514.

Sindhi, S. and Kumar, N. (2012). Corporate environmental responsibility-transitional and evolving. Management of Environmental Quality An International Journal, 23(6): 640 - 657

Surroca, J., Tribó J. and Waddock, S. (2010). Corporate responsibility and financial performance: the role of intangible resources. Strategic Management Journal, 31 (5): 463-490.

Tambunlertchai, K., Kontoleon A. and Khanna, M. (2013). Assessing participation in voluntary environmental programs in the developing world: The role of FDI and export orientation on ISO 14001 adoption in Thailand. Applied Economics, 45 (15): 2039-2048.

Timpere, A.R. (2008). Corporate Social Responsibility. Nova Science Publishers, New York, NY.

Tsai, C.K., Gul, O.K., Nguyen, T.P. and Chia-Wei, H. (2016). Motivations and barriers for corporate social responsibility reporting: Evidence from the airline industry. Journal of Air Transport Management, 57: 184-195.

Valero-Gil, J., Rivera-Torres, P. and Garces-Ayerbe, C. (2017). How is Environmental Proactivity Accomplished? Drivers and Barriers in Firms' ProEnvironmental Change Process, Sustainability, 9, 1327. 
Table A1. List of countries and survey information

\begin{tabular}{|c|c|}
\hline Country & Period when survey was carried out \\
\hline Albania & January and May 2019 \\
\hline Belarus & October 2018 and April 2019 \\
\hline Bosnia-Herzegovina & January and September 2019. \\
\hline Bulgaria & January 2019 and March 2020 \\
\hline Croatia & November 2018 and November 2019 \\
\hline Czech Republic & December 2018 and March 2020 \\
\hline Estonia & November 2018 and January 2020 \\
\hline Georgia & March and January 2020 \\
\hline Hungary & December 2018 and March 2020 \\
\hline Kazakhstan & January and October of 2019 \\
\hline Kosovo & December 2018 and October 2019 \\
\hline Kyrgyzstan & December 2018 and July 2019. \\
\hline Lithuania & December 2018 and January 2020 \\
\hline Latvia & November 2018 and December 2019 \\
\hline Moldova & April and November 2019 \\
\hline Montenegro & January and July 2019 \\
\hline North Macedonia & December 2018 and October 2019 \\
\hline Poland & December 2018 and December 2019 \\
\hline Russia & January and July 2019 \\
\hline Serbia & December 2018 and September 2019 \\
\hline Slovakia & December 2018 and March 2020 \\
\hline Slovenia & December 2018 and November 2019 \\
\hline Tajikistan & January and August 2019 \\
\hline Ukraine & March and December 2019 \\
\hline Uzbekistan & February and August 2019 \\
\hline
\end{tabular}

Table A2. Description of variables

\begin{tabular}{|c|c|}
\hline Variable & $\begin{array}{c}\text { Description } \\
\end{array}$ \\
\hline Eco-actions & 1 if firm, in the last three years, has introduced a eco-action, 0 otherwise \\
\hline Regulation & $\begin{array}{l}\text { Index that captures three types of regulation: (i) occupational safety regulations, (ii) health and hygiene } \\
\text { regulations and finally (iii) environmental regulations. }\end{array}$ \\
\hline Manager Female & 1 if the firm has a top manager female, 0 otherwise \\
\hline Board Director & 1 if the firm have a board directors or supervisory board, 0 otherwise \\
\hline \multicolumn{2}{|r|}{ 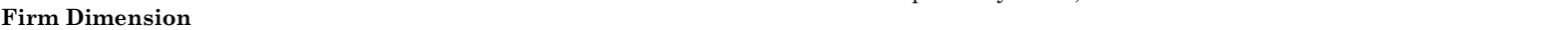 } \\
\hline Small Firms & 1 if a firm has $>=5$ and $<=19$ employees \\
\hline Medium Firms & 2 if a firm has $>=20$ and $<=99$ employees \\
\hline Large Firms & 3 if a firm has $>=100$ employees \\
\hline \multicolumn{2}{|l|}{ Sector activity } \\
\hline Manufacturing & 1 if a firm is a part of manufacturing sector \\
\hline Retail Services & 2 if a firm is a part of retail services sector \\
\hline Other Services & 3 if a firm is a part of other services sector \\
\hline Firm's Age & Difference between the current year and the year the firm registers to start the business activity \\
\hline \multicolumn{2}{|r|}{ Dilleretile } \\
\hline More National Sales & 1 if a firm, in the fiscal year, sold its products more in national market \\
\hline National and International Sales & 2 if a firm, in the fiscal year, sold its products both in national and international market \\
\hline More International Sales & 3 if a firm, in the fiscal year, sold its products more in international market \\
\hline Trade Globalization & Trade Globalization Index Average 2016-2018 \\
\hline Environmental Performance & Environmental performance Index of 2016 \\
\hline \multicolumn{2}{|l|}{ Country Regions } \\
\hline European Former-USSR Countries & 1 for European Former-USSR Countries \\
\hline Central European Countries & 2 for Central European Countries \\
\hline Former Yugoslavian Countries and Albania & 3 for Former Yugoslavian Countries and Albania \\
\hline Eurasian Former- USSR Countries & 4 for Eurasian Former- USSR Countries \\
\hline \multicolumn{2}{|l|}{ European Union } \\
\hline Non-EU Countries & 0 for non-EU countries \\
\hline European Union Countries & 1 for EU countries \\
\hline Candidate EU Countries & 2 for EU candidate countries \\
\hline
\end{tabular}




\begin{tabular}{|c|c|c|c|c|}
\hline VARIABLES & $\begin{array}{c}(1) \\
\text { Eco-actions } \\
\end{array}$ & $\begin{array}{c}(2) \\
\text { Eco-actions } \\
\end{array}$ & $\begin{array}{c}(3) \\
\text { Eco-actions } \\
\end{array}$ & $\begin{array}{c}(4) \\
\text { Eco-actions } \\
\end{array}$ \\
\hline Regulation & $\begin{array}{c}0.013^{* * *} \\
(0.003)\end{array}$ & $\begin{array}{c}0.013^{* * *} \\
(0.003)\end{array}$ & $\begin{array}{c}0.012^{* * *} \\
(0.003)\end{array}$ & $\begin{array}{c}0.012^{* * * *} \\
(0.003)\end{array}$ \\
\hline \multicolumn{5}{|l|}{ Ref. Other Services } \\
\hline Manufacturing & $\begin{array}{c}0.024^{* * *} \\
(0.008)\end{array}$ & $\begin{array}{c}0.021^{* * *} \\
(0.009)\end{array}$ & $\begin{array}{c}0.035^{* * * *} \\
(0.009)\end{array}$ & $\begin{array}{c}0.033^{* * *} \\
(0.009)\end{array}$ \\
\hline Retail Services & $\begin{array}{l}-0.012 \\
(0.243)\end{array}$ & $\begin{array}{l}-0.010 \\
(0.100)\end{array}$ & $\begin{array}{l}-0.007 \\
(0.010)\end{array}$ & $\begin{array}{c}-0.008 \\
(0.010)\end{array}$ \\
\hline \multicolumn{5}{|l|}{ Ref: Small Firms } \\
\hline Medium Firms & $\begin{array}{c}0.034^{* * *} \\
(0.008)\end{array}$ & $\begin{array}{c}0.033^{* * *} \\
(0.008)\end{array}$ & $\begin{array}{c}0.038^{* * *} \\
(0.008)\end{array}$ & $\begin{array}{c}0.036^{* * *} \\
(0.008)\end{array}$ \\
\hline Large Firms & $\begin{array}{c}0.052^{* * * *} \\
(0.010)\end{array}$ & $\begin{array}{c}0.047^{* * *} \\
(0.010)\end{array}$ & $\begin{array}{c}0.062^{* * *} \\
(0.011)\end{array}$ & $\begin{array}{c}0.059^{* * *} \\
(0.011)\end{array}$ \\
\hline Board of directors & $\begin{array}{c}0.094^{* * * *} \\
(0.009)\end{array}$ & $\begin{array}{l}0.100^{* * * *} \\
(0.009)\end{array}$ & $\begin{array}{l}0.092^{* * *} \\
(0.009)\end{array}$ & $\begin{array}{c}0.093^{* * *} \\
(0.009)\end{array}$ \\
\hline Female Manager & $\begin{array}{c}-0.267^{* * * *} \\
(0.008)\end{array}$ & $\begin{array}{l}-0.024^{* * *} \\
(0.008)\end{array}$ & $\begin{array}{l}-0.020^{* *} \\
(0.008)\end{array}$ & $\begin{array}{l}-0.021^{* *} \\
(0.008)\end{array}$ \\
\hline Firm's Age & $\begin{array}{l}-0.000 \\
(0.000)\end{array}$ & $\begin{array}{c}0.000 \\
(0.000)\end{array}$ & $\begin{array}{r}-0.000 \\
(0.000)\end{array}$ & $\begin{array}{r}-0.000 \\
(0.000)\end{array}$ \\
\hline Affiliation & $\begin{array}{c}0.035^{* * *} \\
(0.013)\end{array}$ & $\begin{array}{l}0.036^{* * *} \\
(0.013)\end{array}$ & $\begin{array}{l}0.036^{* * *} \\
(0.013)\end{array}$ & $\begin{array}{c}0.034^{* * *} \\
(0.013)\end{array}$ \\
\hline \multicolumn{5}{|l|}{ Ref. Firms sell only on national Market } \\
\hline Firms sell only on international market & $\begin{array}{c}0.019 \\
(0.021)\end{array}$ & $\begin{array}{c}0.021 \\
(0.021)\end{array}$ & $\begin{array}{l}-0.003 \\
(0.021)\end{array}$ & $\begin{array}{l}-0.003 \\
(0.021)\end{array}$ \\
\hline Firms sell on national and international market & $\begin{array}{c}0.051^{* * *} \\
(0.009)\end{array}$ & $\begin{array}{c}0.058^{* * *} \\
(0.009)\end{array}$ & $\begin{array}{c}0.046^{* * *} \\
(0.009)\end{array}$ & $\begin{array}{c}0.051^{* * *} \\
(0.009)\end{array}$ \\
\hline Trade Globalization & & & $\begin{array}{l}0.002^{* * *} \\
(0.000)\end{array}$ & $\begin{array}{l}0.003^{* * *} \\
(0.000)\end{array}$ \\
\hline Environmental Performance & & & $\begin{array}{c}-0.006^{* * *} \\
(0.001)\end{array}$ & $\begin{array}{c}-0.004^{* * *} \\
(0.001)\end{array}$ \\
\hline \multicolumn{5}{|l|}{ Ref. European Union Countries } \\
\hline Non-EU Countries & $\begin{array}{l}-0.046^{* * *} \\
(0.008)\end{array}$ & & $\begin{array}{c}-0.072 * * * \\
(0.012)\end{array}$ & \\
\hline Candidate EU Countries & $\begin{array}{c}-0.062^{* * *} \\
(0.013)\end{array}$ & & $\begin{array}{c}-0.097 * * * \\
(0.014)\end{array}$ & \\
\hline \multicolumn{5}{|l|}{ Ref. Central European Countries } \\
\hline European Former-USSR Countries & & $\begin{array}{c}-0.036^{* * *} \\
(0.009)\end{array}$ & & $\begin{array}{l}-0.011 \\
(0.010)\end{array}$ \\
\hline Former Yugoslavian Countries and Albania & & $\begin{array}{c}-0.031^{* * *} \\
(0.011)\end{array}$ & & $\begin{array}{c}-0.048^{* * *} \\
(0.012)\end{array}$ \\
\hline Eurasian Former- USSR Countries & & $\begin{array}{c}-0.036^{* * *} \\
(0.010)\end{array}$ & & $\begin{array}{c}0.011 \\
(0.019) \\
\end{array}$ \\
\hline
\end{tabular}

Table A4. Marginal effect: Interactions

\begin{tabular}{|c|c|c|c|c|}
\hline VARIABLES & $\begin{array}{c}(1) \\
\text { Eco-actions }\end{array}$ & $\begin{array}{c}(2) \\
\text { Eco-actions }\end{array}$ & $\begin{array}{c}(3) \\
\text { Eco-actions }\end{array}$ & $\begin{array}{c}(4) \\
\text { Eco-actions }\end{array}$ \\
\hline Regulation & $\begin{array}{c}0.016^{* * * *} \\
(0.004)\end{array}$ & $\begin{array}{c}0.011^{* * *} \\
(0.004)\end{array}$ & $\begin{array}{c}0.021^{* * *} \\
(0.006)\end{array}$ & $\begin{array}{c}0.012^{* * *} \\
(0.003)\end{array}$ \\
\hline Board of Directors & $\begin{array}{c}0.093^{* * * *} \\
(0.009)\end{array}$ & & & \\
\hline Female Manager & & $\begin{array}{c}-0.019^{* *} \\
(0.008)\end{array}$ & & \\
\hline Age of Firm & & & $\begin{array}{l}-0.000 \\
(0.000)\end{array}$ & \\
\hline Non-Eu Countries & & & & $\begin{array}{c}-0.183^{* * *} \\
(0.023)\end{array}$ \\
\hline Candidate Eu Countries & & & & $\begin{array}{c}-0.600 * * * \\
(0.188)\end{array}$ \\
\hline Environmental Performance & & & & \\
\hline Board of Directors* Regulation & $\begin{array}{c}-0.019^{* *} \\
(0.008)\end{array}$ & & & \\
\hline Female Manager*Regulation & & $\begin{array}{c}0.006 \\
(0.008)\end{array}$ & & \\
\hline Firm's Age*Regulation & & & $\begin{array}{c}-0.000^{*} \\
(0.000)\end{array}$ & \\
\hline Non- Eu Countries* Neighboring Countries & & & & $\begin{array}{c}0.178^{* * *} \\
(0.031)\end{array}$ \\
\hline Candidate Eu Countries*Neighboring Countries & & & & $\begin{array}{l}1.249^{* *} \\
(0.494)\end{array}$ \\
\hline
\end{tabular}

Standard errors in parentheses ${ }^{* * *} \mathrm{p}<0.01,{ }^{* *} \mathrm{p}<0.05,{ }^{*} \mathrm{p}<0.10$ 
Table 4. Marginal Effect: Effect of regulation on eco-action categories

\begin{tabular}{|c|c|c|c|c|c|c|c|c|}
\hline VARIABLES & $\begin{array}{c}\text { (1) } \\
\text { Machinery Upgrades }\end{array}$ & $\begin{array}{c}\text { (2) } \\
\text { Machinery Upgrades }\end{array}$ & $\begin{array}{c}(3) \\
\text { Energy Saving }\end{array}$ & $\begin{array}{c}(4) \\
\text { Energy Saving }\end{array}$ & $\begin{array}{l}\text { Pollution Control } \\
\text { Pall }\end{array}$ & $\begin{array}{l}{ }^{(6)} \\
\text { Pollution Control }\end{array}$ & $\begin{array}{l}\quad(7) \\
\text { Recycling waste and } \\
\text { water management }\end{array}$ & $\begin{array}{l}\text { (8) } \\
\text { Recycling waste and } \\
\text { water management }\end{array}$ \\
\hline$\overline{\text { Regulation }}$ & $\begin{array}{c}0.020^{* * *} \\
(0.004)\end{array}$ & $\begin{array}{c}0.020^{* * * *} \\
(0.004)\end{array}$ & $\begin{array}{c}0.015^{* * *} \\
(0.004)\end{array}$ & $\begin{array}{c}0.015^{* * *} \\
(0.004)\end{array}$ & $\begin{array}{c}0.018^{* * *} \\
(0.004)\end{array}$ & $\begin{array}{c}0.018^{* * *} \\
(0.004)\end{array}$ & $\begin{array}{c}0.016^{* * *} \\
(0.004)\end{array}$ & $\begin{array}{c}0.011^{* * *} \\
(0.004)\end{array}$ \\
\hline \multicolumn{3}{|l|}{ Ref. Other Services } & & & & & & \\
\hline & $(0.010)$ & $\begin{array}{c}0.08911) \\
(0.011)\end{array}$ & $(0.010)$ & $(0.010)$ & $\begin{array}{l}.04909) \\
(0.009)\end{array}$ & $\begin{array}{c}0.050^{* * *} \\
(0.009)\end{array}$ & $\begin{array}{c}0.090^{* * * *} \\
(0.010)\end{array}$ & $\begin{array}{c}0.100^{* * * *} \\
(0.011)\end{array}$ \\
\hline Retail Services & $\begin{array}{l}-0.033^{*} \\
(0.013)\end{array}$ & $\begin{array}{l}-0.029^{*} \\
(0.013)\end{array}$ & $\begin{array}{c}0.040^{* * *} \\
(0.012)\end{array}$ & $\begin{array}{c}0.049^{* * *} \\
(0.012)\end{array}$ & $\begin{array}{c}-0.035^{* * *} \\
(0.012)\end{array}$ & $\begin{array}{l}-0.018 \\
(0.012)\end{array}$ & $\begin{array}{c}0.012 \\
(0.013)\end{array}$ & $\begin{array}{c}0.015 \\
(0.013)\end{array}$ \\
\hline \multicolumn{9}{|l|}{ Ref: Small Firms } \\
\hline Medium Firms & $\begin{array}{c}0.038^{* * *} \\
(0.010)\end{array}$ & $\begin{array}{c}0.040^{* * *} \\
(0.013)\end{array}$ & $\begin{array}{c}0.043^{* * *} \\
(0.010)\end{array}$ & $\begin{array}{c}0.048^{* * * *} \\
(0.010)\end{array}$ & $\begin{array}{c}0.037^{* * * *} \\
(0.009)\end{array}$ & $\begin{array}{c}0.042^{* * *} \\
(0.009)\end{array}$ & $\begin{array}{c}0.045^{* * *} \\
(0.010)\end{array}$ & $\begin{array}{c}0.045^{* * *} \\
(0.010)\end{array}$ \\
\hline Large Firms & $\begin{array}{c}0.074 * * * \\
(0.012)\end{array}$ & $\begin{array}{c}0.029^{* * *} \\
(0.013)\end{array}$ & $\begin{array}{c}0.063^{* * *} \\
(0.012)\end{array}$ & $\begin{array}{c}0.075^{* * *} \\
(0.012)\end{array}$ & $\begin{array}{c}0.084^{* * *} \\
(0.010)\end{array}$ & $\begin{array}{c}0.091^{* * *} \\
(0.009)\end{array}$ & $\begin{array}{c}0.101^{* * *} \\
(0.012)\end{array}$ & $\begin{array}{c}0.107^{* * *} \\
(0.012)\end{array}$ \\
\hline Board of Directors & $\begin{array}{c}0.089^{* * * *} \\
(0.010)\end{array}$ & $\begin{array}{c}0.085^{* * * *} \\
(0.010)\end{array}$ & $\begin{array}{c}0.091 * * * \\
(0.010)\end{array}$ & $\begin{array}{c}0.088^{* * * *} \\
(0.010)\end{array}$ & $\begin{array}{c}0.074^{* * *} \\
(0.009)\end{array}$ & $\begin{array}{c}0.071^{* * *} \\
(0.009)\end{array}$ & $\begin{array}{l}0.072^{* * *} \\
(0.010)\end{array}$ & $\begin{array}{c}0.070^{* * * *} \\
(0.010)\end{array}$ \\
\hline \multirow[t]{2}{*}{ Female Manager } & $-0.044^{* * *}$ & $-0.037^{* * *}$ & -0.016 & -0.007 & $-0.048^{* * *}$ & $-0.034^{* * *}$ & -0.007 & -0.004 \\
\hline & $(0.011)$ & $(0.011)$ & $(0.010)$ & $(0.010)$ & $(0.010)$ & $(0.009)$ & $(0.010)$ & $(0.010)$ \\
\hline Firm's Age & $\begin{array}{l}-0.000 \\
(0.000)\end{array}$ & $\begin{array}{l}-0.000 \\
(0.000)\end{array}$ & $\begin{array}{c}0.000 \\
(0.000)\end{array}$ & $\begin{array}{l}0.001^{*} \\
(0.000)\end{array}$ & $\begin{array}{l}0.000 \\
(0.000)\end{array}$ & $\begin{array}{l}0.000 \\
(0.000)\end{array}$ & $\begin{array}{c}0.000 \\
(0.000)\end{array}$ & $\begin{array}{c}0.000 \\
(0.000)\end{array}$ \\
\hline Affiliation & $\begin{array}{c}0.052^{* * *} \\
(0.014)\end{array}$ & $\begin{array}{c}0.054^{* * * *} \\
(0.014)\end{array}$ & $\begin{array}{c}0.040^{* * * *} \\
(0.014)\end{array}$ & $\begin{array}{c}0.046 * * * * \\
(0.014)\end{array}$ & $\begin{array}{l}0.001 \\
(0.012)\end{array}$ & $\begin{array}{l}0.008 \\
(0.012)\end{array}$ & $\begin{array}{l}0.039^{* * *} \\
(0.014)\end{array}$ & $\begin{array}{c}0.039^{* * * *} \\
(0.014)\end{array}$ \\
\hline \multicolumn{9}{|l|}{ Ref. Firms sell only on national Market } \\
\hline $\begin{array}{l}\text { Firms sell only on international market } \\
\text { Fint }\end{array}$ & $\begin{array}{c}0.081 * * * \\
(0.025)\end{array}$ & $\begin{array}{l}0.057 * * \\
(0.025)\end{array}$ & $\begin{array}{c}0.025 \\
(0.024)\end{array}$ & $\begin{array}{c}0.008 \\
(0.024)\end{array}$ & $\begin{array}{c}0.031 \\
(0.021)\end{array}$ & $\begin{array}{l}0.036^{*} \\
(0.021)\end{array}$ & $\begin{array}{c}0.025 \\
(0.024)\end{array}$ & $\begin{array}{c}0.013 \\
(0.024)\end{array}$ \\
\hline \multirow[t]{2}{*}{ Firms sell on national and international market } & $\begin{array}{c}0.083^{* * * *} \\
(0.010)\end{array}$ & $\begin{array}{l}0.075^{* * * *} \\
(0.010)\end{array}$ & $\begin{array}{c}0.043^{* * *} \\
(0.010)\end{array}$ & $\begin{array}{c}0.042^{* * *} \\
(0.010)\end{array}$ & $\begin{array}{c}0.045^{* * *} \\
(0.009)\end{array}$ & $\begin{array}{c}0.056^{* * *} \\
(0.009)\end{array}$ & $\begin{array}{c}0.063^{* * *} \\
(0.010)\end{array}$ & $\begin{array}{c}0.058 * * * \\
(0.010)\end{array}$ \\
\hline & & $\begin{array}{l}0.002^{* * *} \\
(0.000)\end{array}$ & $(0.010)$ & $\begin{array}{l}0.001^{* *} \\
(0.000)\end{array}$ & $(0.009)$ & $\begin{array}{l}-0.001^{* * *} \\
(0.000)\end{array}$ & $(0.010)$ & $\begin{array}{l}(0.010) \\
0.002^{*} \\
0.000)\end{array}$ \\
\hline Environmental Performance & & $\begin{array}{l}-0.005^{* * *} \\
(0.001)\end{array}$ & & $\begin{array}{l}-0.0099^{* * *} \\
(0.001)\end{array}$ & & $\begin{array}{l}-0.008^{* * *} \\
(0.001)\end{array}$ & & $\begin{array}{l}-0.005^{* * *} \\
(0.001)\end{array}$ \\
\hline $\begin{array}{l}\text { Ref. European Countries } \\
\text { No EU Countries }\end{array}$ & $\begin{array}{c}-0.050^{* * *} \\
(0.010)\end{array}$ & $\begin{array}{l}-0.054^{* * *} \\
(0.014)\end{array}$ & $\begin{array}{r}-0.004 \\
(0.009)\end{array}$ & $\begin{array}{c}-0.072^{* * *} \\
(0.014)\end{array}$ & $\begin{array}{c}0.071^{* * * *} \\
(0.008)\end{array}$ & $\begin{array}{c}-0.057^{* * *} \\
(0.013)\end{array}$ & $\begin{array}{c}-0.161^{* * *} \\
(0.009)\end{array}$ & $\begin{array}{l}-0.162^{* * *} \\
(0.014)\end{array}$ \\
\hline Candidate EU Countries & $\begin{array}{l}-0.088^{* * *} \\
(0.016)\end{array}$ & $\begin{array}{l}-0.108^{* * *} \\
(0.17)\end{array}$ & $-0.026^{*}$ & $\begin{array}{l}-0.082^{* * *} \\
(0.016)\end{array}$ & $0.044^{* * *}$ & $-0.027^{*}$ & $\begin{array}{l}-0.126^{* * * *} \\
(0.015)\end{array}$ & $\begin{array}{l}-0.147^{* * *} \\
(0.017)\end{array}$ \\
\hline
\end{tabular}

